\title{
Connexin-43 is a promising target for pulmonary hypertension due to hypoxaemic lung disease
}

\author{
Claire Bouvard ${ }^{1,2}$, Nafiisha Genet $^{1,2}$, Carole Phan ${ }^{3,4}$, Baptiste Rode ${ }^{1,2}$, \\ Raphaël Thuillet ${ }^{3,4}$, Ly Tu $^{3,4}$, Paul Robillard ${ }^{1,2}$, Marilyne Campagnac ${ }^{1,2}$, \\ Raffaella Soleti ${ }^{5}$, Eric Dumas De La Roque ${ }^{1,6}$, Frédéric Delcambre ${ }^{6}$, \\ Laurent Cronier ${ }^{7}$, Thibaud Parpaite ${ }^{1,2}$, Elise Maurat ${ }^{1,2}$, Patrick Berger (1) ${ }^{1,2,6}$, \\ Jean-Pierre Savineau ${ }^{1,2}$, Roger Marthan ${ }^{1,2,6}$, Christophe Guignabert (10) ${ }^{3,4}$, \\ Véronique Freund-Michel ${ }^{1,2}$ and Christelle Guibert (ib ${ }^{1,2}$
}

@ERSpublications

Connexin (Cx)-43, part of intercellular channels, is increased in patients with chronic hypoxia-induced pulmonary hypertension (CH-PH). It is crucial in lung inflammation and pulmonary artery remodelling in mice with $\mathrm{CH}-\mathrm{PH}$, suggesting $\mathrm{Cx} 43$ as a therapeutic option http://bit.ly/35zNkGm

Cite this article as: Bouvard C, Genet N, Phan C, et al. Connexin-43 is a promising target for pulmonary hypertension due to hypoxaemic lung disease. Eur Respir J 2020; 55: 1900169 [https://doi.org/10.1183/ 13993003.00169-2019].

ABSTRACT The mechanisms underlying pulmonary hypertension (PH) are complex and multifactorial, and involve different cell types that are interconnected through gap junctional channels. Although connexin (Cx)-43 is the most abundant gap junction protein in the heart and lungs, and critically governs intercellular signalling communication, its contribution to $\mathrm{PH}$ remains unknown. The focus of the present study is thus to evaluate $\mathrm{Cx} 43$ as a potential new target in $\mathrm{PH}$.

Expressions of $\mathrm{Cx} 37, \mathrm{Cx} 40$ and $\mathrm{Cx} 43$ were studied in lung specimens from patients with idiopathic pulmonary arterial hypertension (IPAH) or $\mathrm{PH}$ associated with chronic hypoxaemic lung diseases (chronic hypoxia-induced pulmonary hypertension (CH-PH)). Heterozygous $\mathrm{Cx} 43$ knockdown $\mathrm{CD} 1\left(\mathrm{Cx} 43^{+/-}\right)$and wild-type littermate $\left(\mathrm{Cx} 43^{+/+}\right)$mice at 12 weeks of age were randomly divided into two groups, one of which was maintained in room air and the other exposed to hypoxia (10\% oxygen) for 3 weeks. We evaluated pulmonary haemodynamics, remodelling processes in cardiac tissues and pulmonary arteries (PAs), lung inflammation and PA vasoreactivity.

Cx43 levels were increased in PAs from CH-PH patients and decreased in PAs from IPAH patients; however, no difference in $\mathrm{Cx} 37$ or $\mathrm{Cx} 40$ levels was noted. Upon hypoxia treatment, the $\mathrm{Cx} 43^{+/-}$mice were partially protected against $\mathrm{CH}-\mathrm{PH}$ when compared to $\mathrm{Cx} 43^{+/+}$mice, with reduced pulmonary arterial muscularisation and inflammatory infiltration. Interestingly, the adaptive changes in cardiac remodelling in $\mathrm{Cx} 43^{+/-}$mice were not affected. PA contraction due to endothelin-1 (ET-1) was increased in Cx43 $3^{+/-}$ mice under normoxic and hypoxic conditions.

Taken together, these results indicate that targeting $\mathrm{Cx} 43$ may have beneficial therapeutic effects in $\mathrm{PH}$ without affecting compensatory cardiac hypertrophy. 


\section{Introduction}

Pulmonary hypertension (PH) encompasses a group of devastating cardiovascular diseases with high morbidity and mortality, comprising idiopathic pulmonary arterial hypertension (IPAH) and forms of $\mathrm{PH}$ associated with cardiopulmonary diseases such as hypoxaemic chronic lung diseases (chronic hypoxia-induced pulmonary hypertension $(\mathrm{CH}-\mathrm{PH})$ ) [1]. All forms of $\mathrm{PH}$ are characterised by progressive remodelling of distal pulmonary arteries (PAs) and vasoconstriction/relaxation imbalance leading to sustained elevated mean pulmonary arterial pressure (PAP) over $25 \mathrm{mmHg}$ at rest. As a consequence, hypertrophic and failing right heart is responsible for premature patient death $[2,3]$. Recent evidence also points out the importance of inflammation in all forms of $\mathrm{PH}[4,5]$. $\mathrm{PH}$ is still incurable and lung transplantation is too often the only therapeutic option with a survival rate of $52-75 \%$ at 5 years after surgery [1]. Moreover, treatment for $\mathrm{CH}-\mathrm{PH}$ is currently based on drugs developed for IPAH without clear evidence of their efficacy on $\mathrm{CH}-\mathrm{PH}$ [1]. $\mathrm{PH}$ and $\mathrm{CH}-\mathrm{PH}$ thus remain an important challenge and development of new drugs specific to different $\mathrm{PH}$ forms may be a key point.

In $\mathrm{PH}$, two essential actors are involved in PA dysfunction: pulmonary artery endothelial cells (PA-ECs) and pulmonary artery smooth muscle cells (PA-SMCs) [6]. Under physiological conditions, PA-ECs and PA-SMCs are responsible for fine control of PA tone through subtle crosstalk involving direct myoendothelial communications (gap junctions) [7]. Gap junctions are clusters of intercellular channels composed of various structural proteins (connexins $(\mathrm{Cx})$ ) also essential for spreading cellular signalling $[7,8]$. Our group and others have previously shown that $\mathrm{Cx} 37, \mathrm{Cx} 40$ and $\mathrm{Cx} 43$ are expressed in rat, mouse and human PAs and such expression is modified in experimental models of $\mathrm{PH}$ as well as in patients with IPAH; however, disparities have been observed between the different studies [8-14]. Interestingly, $\mathrm{Cx} 43$ is known to be involved in tone regulation, cell proliferation and inflammatory infiltration in vessels, which are the main hallmarks of $\mathrm{PH}[7,8,10,15-17]$. $\mathrm{Cx} 40, \mathrm{Cx} 43$ and $\mathrm{Cx} 45$ are also expressed in cardiac tissue, with $\mathrm{Cx} 43$ being the most abundant. Moreover, $\mathrm{Cx} 43$ expression and localisation are modified in hypertrophic cardiac pathologies, including in right-ventricle hypertrophy in the well-established monocrotaline-induced rat model of $\mathrm{PH}$ [18-20]. However, cardiac Cx43 expression has not been studied in $\mathrm{CH}-\mathrm{PH}$ so far.

We hypothesised that $\mathrm{Cx} 43$ may contribute to $\mathrm{PH}$ and especially $\mathrm{CH}-\mathrm{PH}$. Using heterozygous $\mathrm{Cx} 43$ knock-down mice $\left(\mathrm{Cx}_{4} 3^{+-}\right)$, we addressed the expression and the role of $\mathrm{Cx} 43$ on PA reactivity, remodelling processes in cardiac tissues and PA and lung inflammation in an experimental model of $\mathrm{CH}-\mathrm{PH}$. From a translational point of view, we also evaluated $\mathrm{Cx} 43$ expression in human $\mathrm{PH}$, such as $\mathrm{CH}-\mathrm{PH}$ as well as IPAH, in order to examine the relative specificity of changes in these two severe clinical entities.

\section{Methods}

Further details and a full description of all methods are provided in the supplementary material.

\section{Human material}

For the in vitro and in situ studies we used lung specimens obtained during lung transplantation from patients with IPAH or $\mathrm{CH}-\mathrm{PH}$. The six patients with $\mathrm{CH}-\mathrm{PH}$ had the following diseases associated to $\mathrm{PH}$ : emphysema, Kartagener syndrome, cystic fibrosis, familial IPAH (with severe hypoxaemia, oxygen tension $\left(P_{\mathrm{O}_{2}}\right)=59 \mathrm{mmHg}$ ), pulmonary veno-occlusive disease and cystic lung disease. The mean age of the patients was $51.3 \pm 6.6$ years and the group included three women and three men. The mean of the mean PAP was $43.5 \pm 2.6 \mathrm{mmHg}$. Vessels used were intrapulmonary arteries of the second and third order. Control lung tissue (intrapulmonary arteries) was obtained during lobectomy or pneumonectomy for localised lung cancer. Preoperative cardiological evaluation including echocardiography was performed in the controls to rule out $\mathrm{PH}$ and the lung specimens from the controls were collected at a distance from tumour foci. PA-SMCs exposed to in vitro chronic hypoxia $(\mathrm{CH})$ (supplemental figure S2) were obtained from extrapulmonary arteries of healthy lung donors during lung transplantation. The study was approved by the local ethics committees (Comité de Protection des Personnes, Sud-Ouest et Outre-mer III, Bordeaux,

Affiliations: ${ }^{1}$ INSERM, Centre de Recherche Cardio-Thoracique de Bordeaux, U1045, Pessac, France. ${ }^{2}$ UnivBordeaux, Centre de Recherche Cardio-Thoracique de Bordeaux, U1045, Bordeaux, France. ${ }^{3}$ INSERM UMR_S 999. Hôpital Marie Lannelongue, Le Plessis-Robinson, France. 'Université Paris-Saclay, Faculté de Médecine, Le Kremlin-Bicêtre, France. ${ }^{5}$ SOPAM, U1063, INSERM, Univ Angers, SFR ICAT, Angers, France. ${ }^{6} \mathrm{CHU}$ de Bordeaux, Pessac, France. ${ }^{7}$ Laboratoire Signalisation et Transports loniques Membranaires, CNRS ERL 7003, Université de Poitiers, Poitiers, France.

Correspondence: Christelle Guibert, Centre de Recherche Cardio-Thoracique de Bordeaux, INSERM U1045, Plateforme Technologique d'Innovation Biomédicale (PTIB), Hôpital Xavier Arnozan, Avenue du Haut Lévêque, 33604 Pessac Cedex, France. E-mail: christelle.guibertQu-bordeaux.fr 
France; Comité de Protection des Personnes, Ile de France VII, Le Kremlin-Bicêtre, France) and informed consent was obtained from each individual patient.

\section{Isolation, culture and treatment of human pulmonary vascular cells}

Human pulmonary microvascular endothelial cells (PM-ECs) and PA-SMCs were obtained and cultured as previously described [5, 21-23]. PA-SMCs were exposed to $\mathrm{CH}$ conditions in vitro (1\% oxygen, the " $\mathrm{CH}$ group") as previously described [24]. PA-SMCs of the control group were exposed to normoxia (N) conditions ( $21 \%$ oxygen, $74 \%$ nitrogen and $5 \%$ carbon dioxide, the "N group"). Cells were used between passages three and six. Further details are provided in the supplementary material.

\section{Animal experiments}

All animal studies conformed to the Declaration of Helsinki conventions for the use and care of animals. Agreement (number A33-063-907) was obtained from the French authorities and all protocols used were approved by the local ethics committee (Comité d'éthique de Bordeaux no. 50, protocol number APAFIS\#9212-2017031018562273 v5). Genetically modified adult male CD1 mice (8-12 weeks, Gja1 ${ }^{\mathrm{tm} 1 \mathrm{Kdr}}$, Jackson Laboratory, Bar Harbor, ME, USA) were used and compared to their wild-type litter mates. Mutation is due to the in-frame insertion of a promoterless neomycin (Neo) gene into exon 2 of the $\mathrm{Cx} 43$ (Gja1) gene [25]. Gja1 ${ }^{\mathrm{tm} 1 \mathrm{Kdr}}$ homozygous $\left(\mathrm{Cx} 43^{-/-}\right)$mice die at birth due to a severe heart defect [25]. Consequently, only heterozygous $\left(\mathrm{Cx} 43^{+/-}\right)$and wild-type $\left(\mathrm{Cx} 43^{+/+}\right)$mice were used for the study. $\mathrm{PH}$ was induced by exposing mice to $\mathrm{CH}$ conditions in a hypobaric chamber $(380 \mathrm{mmHg}$ ) over 21 days, while control animals were kept under normobaric $\mathrm{N}$ conditions (room air). The number of mice used is specified in the legend of the figures for each set of experiments. Further details are provided in the supplementary material.

\section{Statistical analysis}

All data are expressed as mean \pm SEM of $n$ independent observations. Two-way ANOVA was used to compare concentration-response curves and a Mann-Whitney test was used when comparing two groups. For all other parameters, one-way ANOVA was used to assess differences among groups, followed by adapted post hoc tests (Dunn tests). Values of p less than 0.05 were considered significant. Analyses were performed using GraphPad Prism version 6.07 (Graphpad Software, La Jolla, CA, USA).

\section{Results}

Cx43 expression varies in the PA vascular bed in experimental and human PH

$\mathrm{Cx} 43$ protein levels were increased in $\mathrm{PAs}$ from patients with $\mathrm{CH}-\mathrm{PH}$ (figure 1a). Interestingly, $\mathrm{Cx} 43$ expression was inversely decreased in human PA-SMCs whereas it was not modified in PM-ECs from patients with IPAH compared to control patients (figures $1 \mathrm{~b}$ and $1 \mathrm{c}$, respectively). Consistent with these

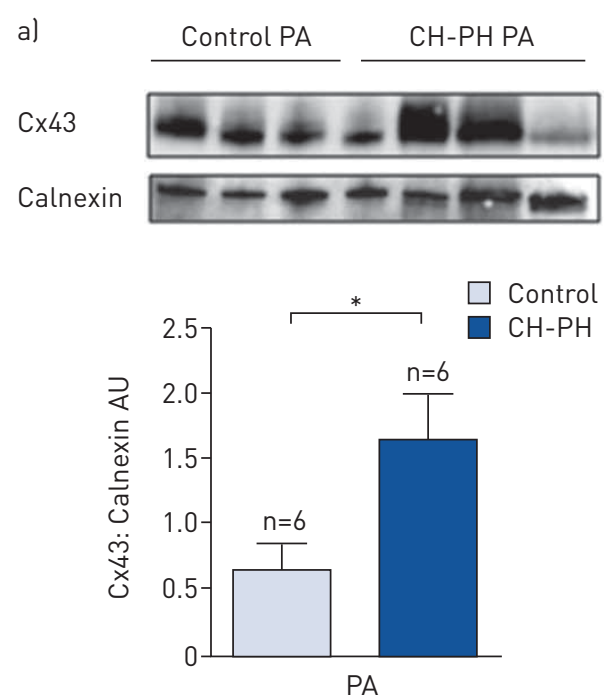

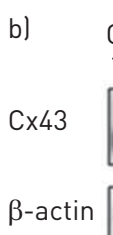
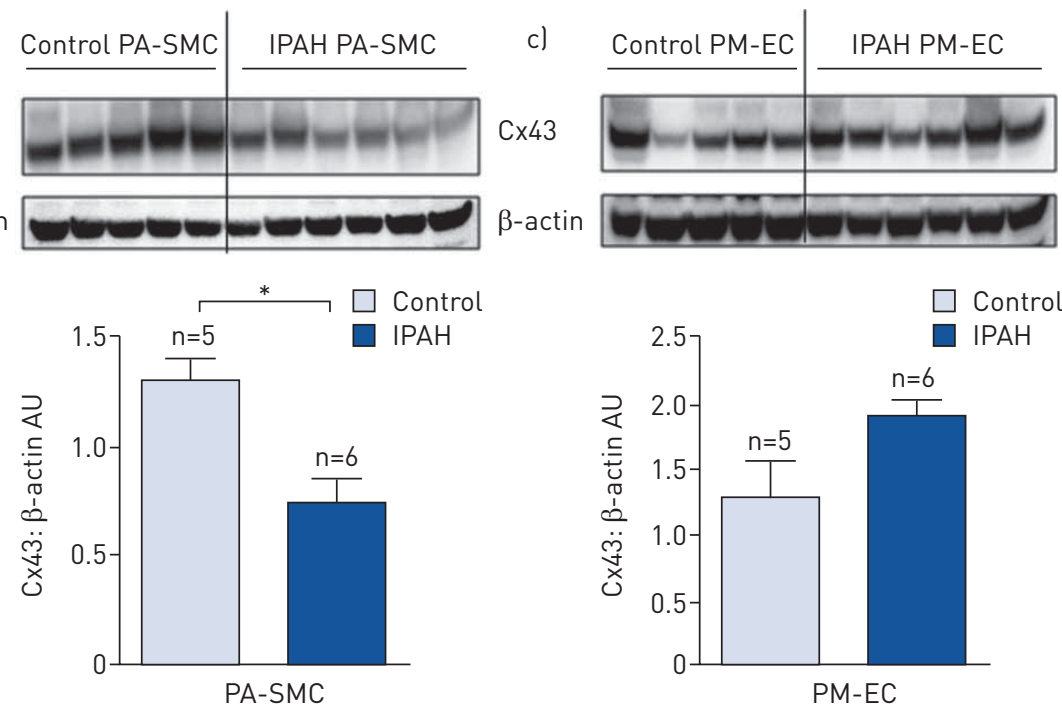

FIGURE 1 Expression of connexin-43 (Cx43) in human pulmonary hypertension (PH). Panels are as follows: (a) expression of Cx43 assessed by

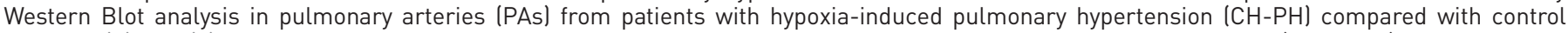

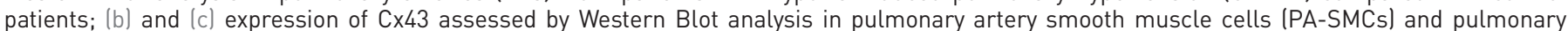
microvascular endothelial cells (PM-ECs) from patients with idiopathic pulmonary arterial hypertension (IPAH) and control patients, respectively. Cx43 expression was normalised to calnexin (la)) or $\beta$-actin ((b) and (c)). Data presented are mean \pm sEM. $n:$ number of patients. *: p<0.05. 
findings, lung section staining showed a strong increase in Cx43 expression in the smooth muscle of PAs from patients with $\mathrm{CH}-\mathrm{PH}$ compared to patients with IPAH or to control patients (figure 2 and supplementary figure S1). Moreover, when PA-SMCs from control patients were exposed to $\mathrm{CH}(1 \%$ oxygen for $48 \mathrm{~h}$ ), Cx43 mRNA levels were increased (supplemental figure S2) suggesting that hypoxia may be responsible for the increased $\mathrm{Cx} 43$ expression in $\mathrm{PAs}$ from $\mathrm{CH}-\mathrm{PH}$ patients.

Cx40 protein expression seemed unchanged in $\mathrm{CH}-\mathrm{PH}$ and IPAH patients (supplemental figure S3, right-hand images), whereas $\mathrm{Cx} 37$ protein expression appeared to be decreased in PA-SMCs from IPAH patients and unchanged in PA-SMCs from $\mathrm{CH}-\mathrm{PH}$ patients (supplemental figure S3, left-hand images).
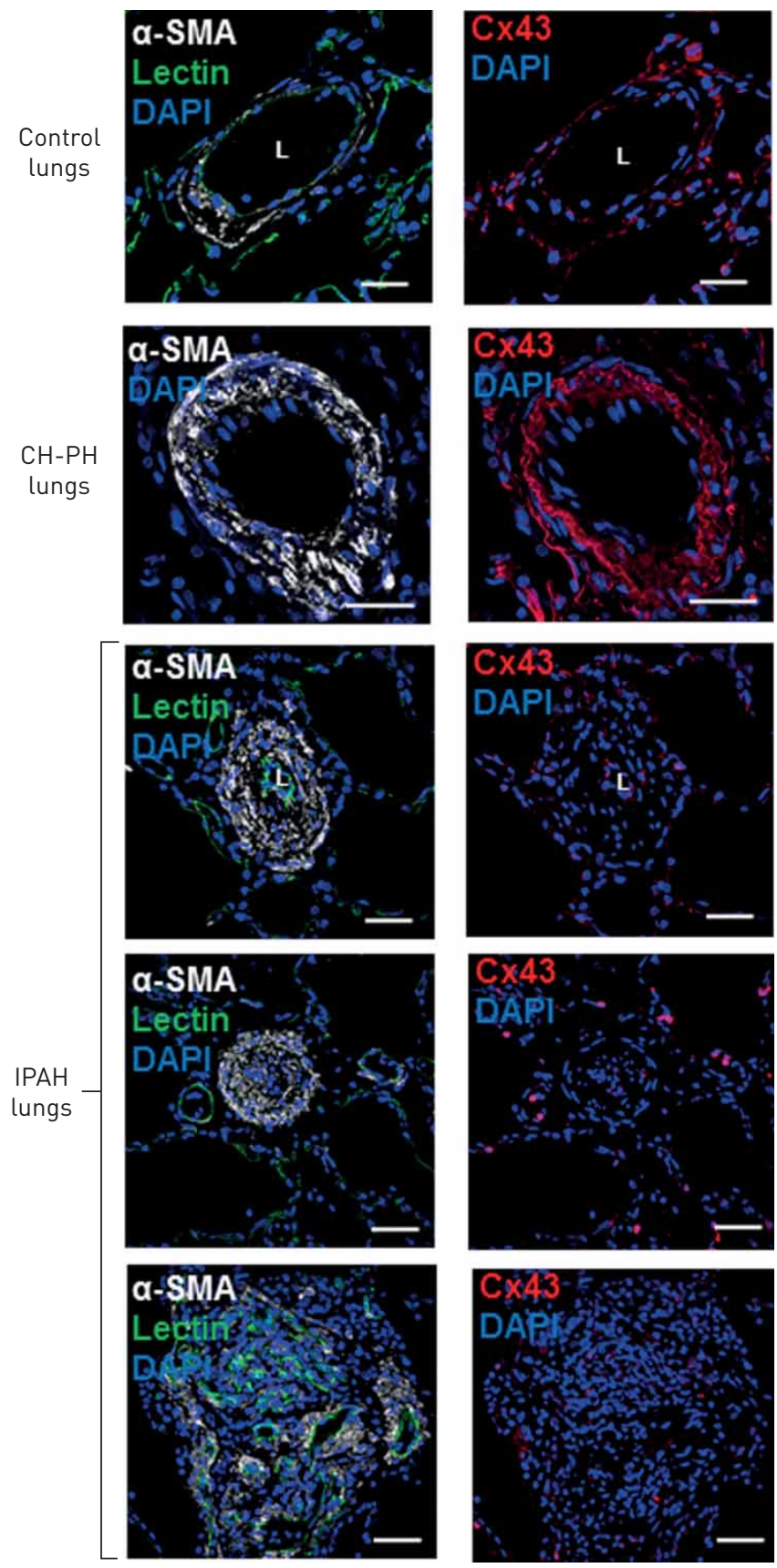

FIGURE 2 Localisation and expression of connexin-43 ( $\mathrm{C} \times 43)$ in human pulmonary hypertension (PH) as assessed by immunofluorescent staining in sections of intrapulmo-nary arteries from lungs of patients with hypoxia-induced pulmonary hypertension $(\mathrm{CH}-\mathrm{PH})$ or idiopathic pulmonary arterial hypertension (IPAH) compared with control patients. Cx43 is labelled in red, pulmonary artery (PA) media is labelled in white using an antibody against $\alpha$-smooth muscle actin ( $\alpha$-SMA), endothelium is labelled in green with a lectin and nuclei are labelled in blue with 4',6-diamidino-2-phenylindole (DAPI). Scale bars $=20 \mu \mathrm{m}$. L: PA lumen. 


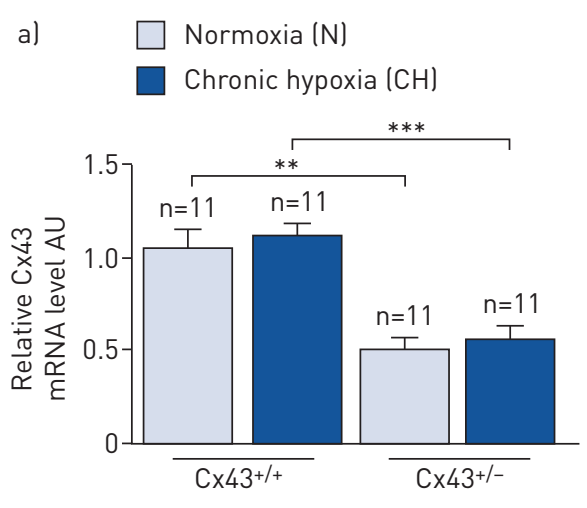

c)
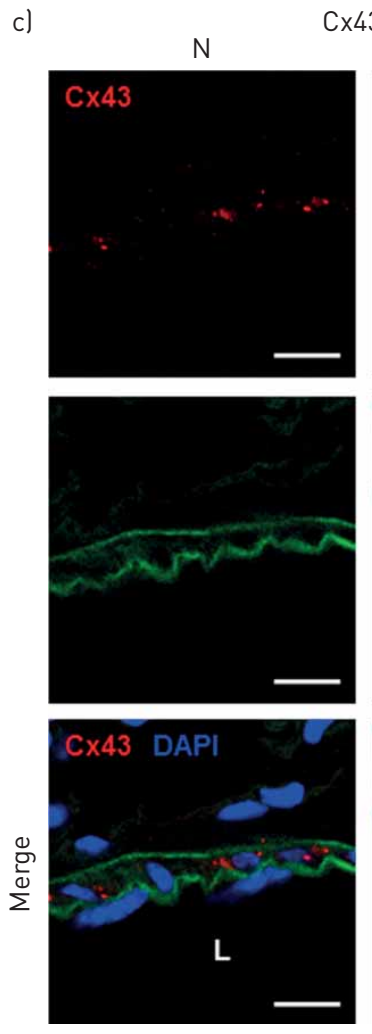

$\mathrm{C} \times 4^{+/+}$
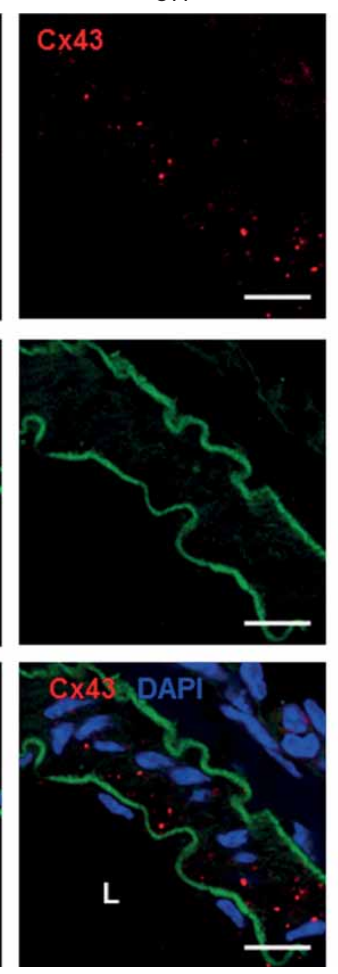

b)

\begin{tabular}{|c|c|c|c|}
\hline \multicolumn{2}{|c|}{$\mathrm{C} \times 43^{+/+}$} & \multicolumn{2}{|c|}{ Cx43+/- } \\
\hline $\mathrm{N}$ & $\mathrm{CH}$ & $\mathrm{N}$ & $\mathrm{CH}$ \\
\hline
\end{tabular}

Cx43

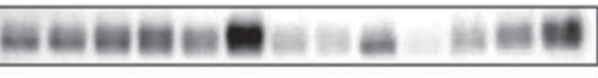

GAPDH
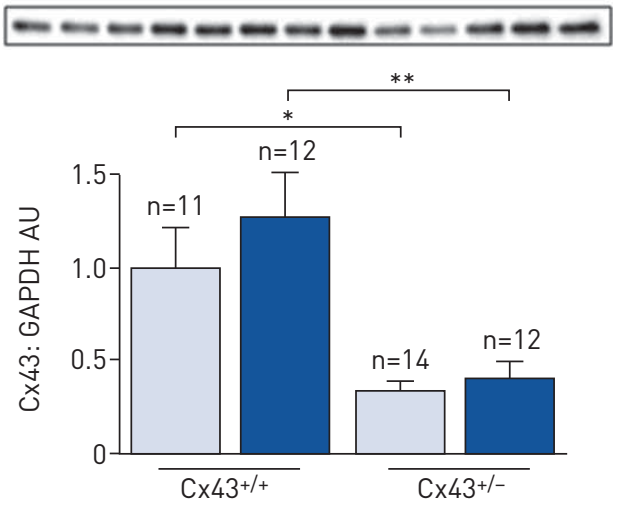

$\mathrm{C} \times 43^{+/-}$ $\mathrm{N}$
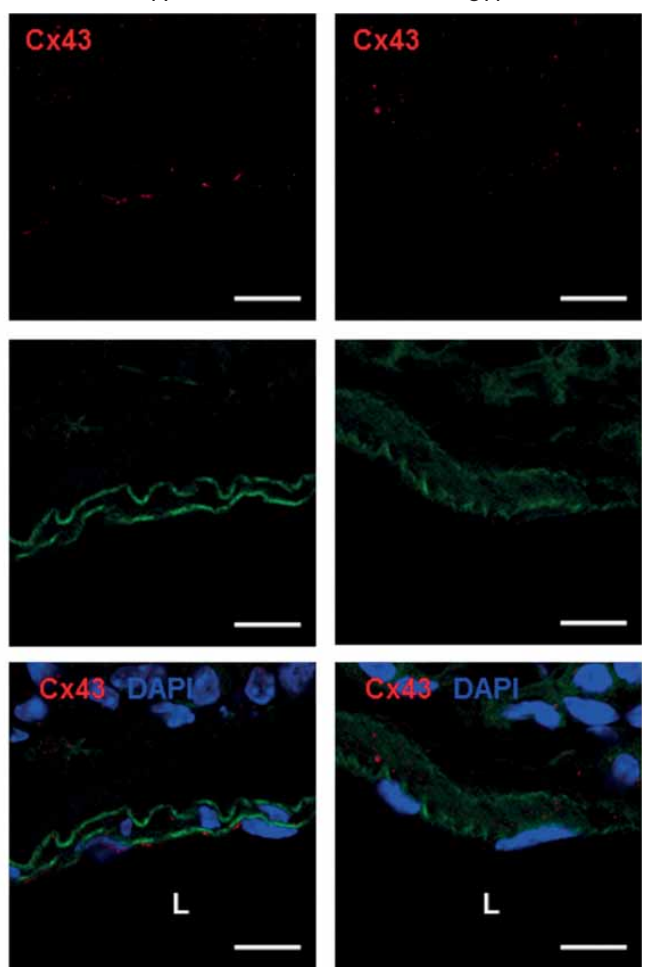

FIGURE 3 Localisation and expression of connexin-43 (Cx43) in intrapulmonary arteries from mice with hypoxia-induced pulmonary hypertension $(\mathrm{CH}-\mathrm{PH})$, comparing $\mathrm{C} \times 43^{+/-}$mice with $\mathrm{C} \times 43^{+/+}$mice under conditions of normoxia $(\mathrm{N})$ and chronic hypoxia $(\mathrm{CH})$. Cx43 mRNA and protein levels were assessed by quantitative PCR and Western Blot analysis (panels (a) and (b), respectively). Cx43 protein expression was normalised to glyceraldehyde-3-phosphate dehydrogenase (GAPDH). Panel (c) shows expression and localisation of $\mathrm{C} \times 43$ protein as assessed by immunofluorescent staining in sections of intrapulmonary arteries from the mice lungs from different experimental groups. Cx43 is labelled in red, nuclei are labelled in blue using 4',6-diamidino-2-phenylindole (DAPI) and elastic lamina autofluorescence is labelled in green. Data presented are mean \pm SEM. Scale bars $=10 \mu \mathrm{m}$. $n$ : number of mice; L: pulmonary artery (PA) lumen. ${ }^{*}: p<0.05$; ${ }^{* *}: p<0.01 ;{ }^{* * *}: p<0.001$

In $\mathrm{Cx} 43^{+/+}$and $\mathrm{Cx} 43^{+/-}$mice, expression of both $\mathrm{Cx} 43$ mRNA and protein was similar in PAs from $\mathrm{N}$ mice compared to $\mathrm{CH}$ mice (figures $3 \mathrm{a}$ and $3 \mathrm{~b}$ ). Interestingly, $\mathrm{Cx} 43$ expression seems to be more abundant close to the plasma membrane in $\mathrm{CH} \mathrm{Cx} 43^{+/+}$mice compared to $\mathrm{N} \mathrm{Cx} 43^{+/+}$mice (supplemental figure S4). As expected, expression of both $\mathrm{Cx} 43 \mathrm{mRNA}$ and protein was significantly decreased under $\mathrm{N}$ as well as $\mathrm{CH}$ conditions in $\mathrm{Cx} 43^{+/-}$mice (figures $3 \mathrm{a}$ and $3 \mathrm{~b}$ ). Immunofluorescence assays revealed that, 
in $\mathrm{Cx} 43^{+/+}$mice, $\mathrm{Cx} 43$ was expressed in the media between the two elastic lamina shown in green (figure $3 \mathrm{c}$ and supplemental figure S5) under both $\mathrm{N}$ and $\mathrm{CH}$ conditions. These experiments also confirmed the decrease of $\mathrm{Cx} 43$ in $\mathrm{Cx} 43^{+/-}$mice (figure $3 \mathrm{c}$ and supplemental figure S5). In accordance with the previous results, mRNA levels for $\mathrm{Cx} 37$ and $\mathrm{Cx} 40$ were not significantly different between the four experimental groups of mice (supplemental figures S6a and S6b, respectively), thus suggesting that the decrease in Cx43 in $\mathrm{Cx} 43^{+/-}$mice is not compensated by any modification of $\mathrm{Cx} 37$ and/or $\mathrm{Cx} 40$ expression.

\section{Role of Cx43 in pulmonary vascular remodelling and right-ventricular hypertrophy in mice} chronically exposed to hypoxia

By using haematoxylin-eosin staining, we observed a significant increase in pulmonary arterial wall thickness in $\mathrm{Cx}_{4} 3^{+/+}$mice with $\mathrm{CH}-\mathrm{PH}$ that was not present in $\mathrm{Cx} 43^{+/-}$mice with $\mathrm{CH}-\mathrm{PH}$ (figure $4 \mathrm{a}$ and $4 \mathrm{~b}$ ). Proliferating cell nuclear antigen (PCNA) expression, which labels proliferating cells, was consistently increased only in PAs (smooth muscle cells and endothelial cells) from $\mathrm{Cx} 43^{+/+}$mice with $\mathrm{CH}-\mathrm{PH}$ (figure $4 \mathrm{c}$ and $4 \mathrm{~d}$ ). No TUNEL-positive cells were detected in PAs from lung sections of the four experimental groups of mice, whereas few TUNEL-positive cells were detected in mouse colon used as a positive control (figure 4e). Thus, $\mathrm{Cx} 43^{+/-}$mice were protected against cell proliferation and intrapulmonary artery remodelling associated to $\mathrm{CH}-\mathrm{PH}$.

In contrast, in the heart, right-ventricular systolic pressure was significantly increased in both $\mathrm{Cx} 43^{+/+}$and $\mathrm{Cx} 43^{+/-}$mice with $\mathrm{CH}-\mathrm{PH}(\mathrm{p}<0.001$, figure $4 \mathrm{f}$ ). Moreover, right-ventricular hypertrophy (as assessed by the Fulton index), a hallmark of right-ventricular remodelling in $\mathrm{PH}$, was also present in $\mathrm{CH}-\mathrm{PH}$ in both $\mathrm{Cx}_{4} 3^{+/+}$and $\mathrm{Cx}_{4} 3^{+/-}$mice $(\mathrm{p}<0.001$, figure $4 \mathrm{~g}$ ). Interestingly, its magnitude was statistically significantly smaller in $\mathrm{Cx} 43^{+/-}$mice compared to $\mathrm{Cx} 43^{+/+}$mice $(\mathrm{p}<0.05$, figure $4 \mathrm{~g})$. Pulmonary artery acceleration time (PAAT), as assessed by echocardiography, is similarly decreased in $\mathrm{Cx} 43^{+/+}$and $\mathrm{Cx} 43^{+/-}$mice under $\mathrm{CH}$ conditions (supplemental figures S7a and S7b), confirming that right-ventricular function is similarly modified in $\mathrm{Cx} 43^{+/+}$and $\mathrm{Cx} 43^{+/-}$mice under $\mathrm{CH}$ conditions (figures $4 \mathrm{f}$ and $4 \mathrm{~g}$ ). Heart rate (HR) measured by pulsed-wave Doppler was similar in all groups of mice (supplemental figure S7c). CD31 immunofluorescent staining and TUNEL experiments were also performed, to measure capillary density and apoptosis respectively, in hearts from all groups of mice (supplemental figure S8). In all groups of mice, capillary density was similar (supplemental figures S8a and S8b) and right-heart apoptosis was absent (supplemental figure S8c), suggesting that, interestingly, heart modifications observed in Cx $43^{+/-}$ mice are not strongly deleterious.

\section{Knocking down of Cx43 prevents hypoxia-induced lung inflammation in mice}

Inflammatory cell infiltration was estimated by CD45 expression and assessed using Western Blot and immunofluorescent labelling. CD45 expression was significantly increased in $\mathrm{Cx} 43^{+/+}$mice with $\mathrm{CH}-\mathrm{PH}$ $(\mathrm{p}<0.001)$, whereas it was almost absent in $\mathrm{Cx} 43^{+/-}$mice (figure $5 \mathrm{a}$ and supplemental figure S9). Consistent with this finding, the number of inflammatory cells was increased in $\mathrm{C} \times 43^{+/+}$mice with $\mathrm{CH}-\mathrm{PH}$ (figure 5b, expansions 5 and 6 , and supplemental figure S9) while such an inflammatory process was not present in $\mathrm{Cx}_{4} 3^{+/-}$mice with $\mathrm{CH}-\mathrm{PH}$ (figure 5b, expansions 7 and 8, and supplemental figure $\mathrm{S} 9$ ). Interestingly, CD45 immunofluorescent staining was localised at the perivascular level of the lung sections (supplemental figure S9). Altogether, these findings indicate that $\mathrm{Cx} 43^{+/-}$mice with $\mathrm{CH}-\mathrm{PH}$ are protected from lung inflammation induced by $\mathrm{CH}$.

Pulmonary arterial contraction and relaxation in $\mathrm{C} \times 43^{+/+}$and $\mathrm{C} \times 43^{+/-}$mice

Pulmonary arterial reactivity to contractile and relaxant agonists was examined in PAs from $\mathrm{Cx} 43^{+/+}$and $\mathrm{Cx}_{4} 3^{+/-}$mice under $\mathrm{N}$ and $\mathrm{CH}$ conditions. In $\mathrm{Cx} 43^{+/-}$mice, the contraction response curve to endothelin-1 (ET-1) was shifted to the left under $\mathrm{N}$ conditions compared to $\mathrm{Cx} 43^{+/+}$mice and the maximal response was increased under $\mathrm{CH}$ conditions (figure 6a). Moreover, following blockade of endothelin receptors with bosentan $\left(20 \mathrm{mg} \cdot \mathrm{kg}^{-1}\right.$ in vivo), carbachol (Carb, $\left.10 \mu \mathrm{M}\right)$ had a significant effect only in $\mathrm{Cx} 43^{+/-}$mice under $\mathrm{CH}$ conditions, confirming that the ET-1 contribution to vasotonus is more important in $\mathrm{Cx}_{4} 3^{+/-}$mice compared to $\mathrm{Cx} 43^{+/+}$mice under $\mathrm{CH}$ conditions (supplemental figure S10).

Contraction response curves to serotonin (5-HT) were identical in $\mathrm{Cx} 43^{+/+}$and $\mathrm{Cx} 43^{+/-}$mice under both $\mathrm{N}$ and $\mathrm{CH}$ conditions (figure $6 \mathrm{~b}$ ). The maximal contractile response to phenylephrine (Phe) was significantly decreased in $\mathrm{Cx} 43^{+/-}$mice compared to $\mathrm{Cx} 43^{+/+}$mice under $\mathrm{N}$ conditions $(\mathrm{p}<0.01$, figure $6 \mathrm{c}$ ), whereas it was significantly increased in $\mathrm{Cx} 43^{+/-}$mice compared to $\mathrm{Cx} 43^{+/+}$mice under $\mathrm{CH}$ conditions $\left(\mathrm{p}<0.05\right.$, figure 6c). Finally, relaxation to Carb was identical in $\mathrm{Cx} 43^{+/-}$and $\mathrm{Cx} 43^{+/+}$mice under $\mathrm{N}$ and $\mathrm{CH}$ conditions (figure $6 \mathrm{~d}$ ). Interestingly, $\mathrm{CH}$ conditions strongly reduced relaxation in both $\mathrm{Cx} 43^{+/-}$and $\mathrm{Cx} 43^{+/+}$mice compared to $\mathrm{N}$ conditions, suggesting the existence of an endothelial dysfunction in $\mathrm{CH}-\mathrm{PH}$ as previously described [26]. Labelling with von Willebrand factor (vWF), a marker of endothelium, did 

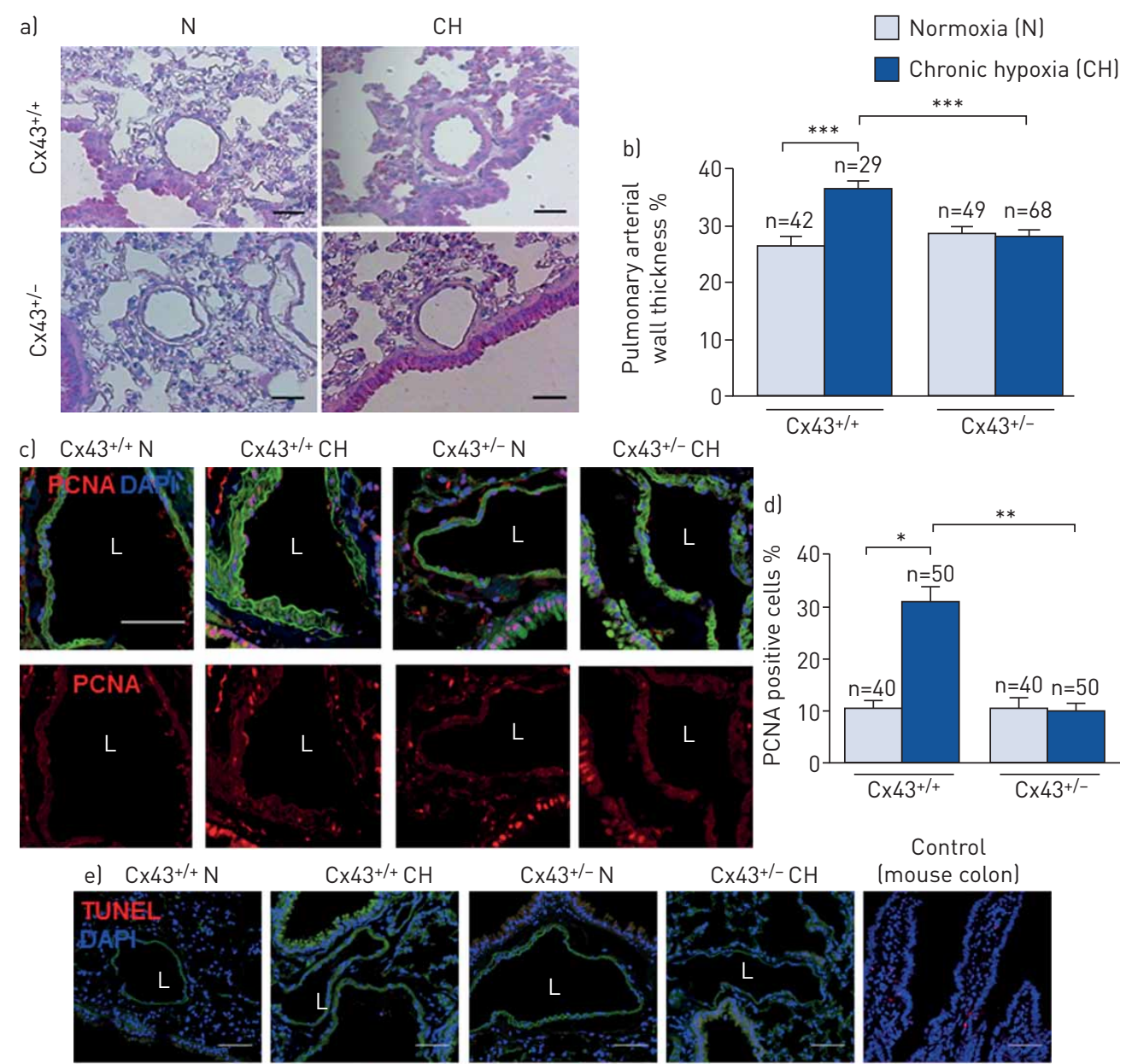

$\mathrm{C} \times 43^{+/+} \mathrm{CH}$
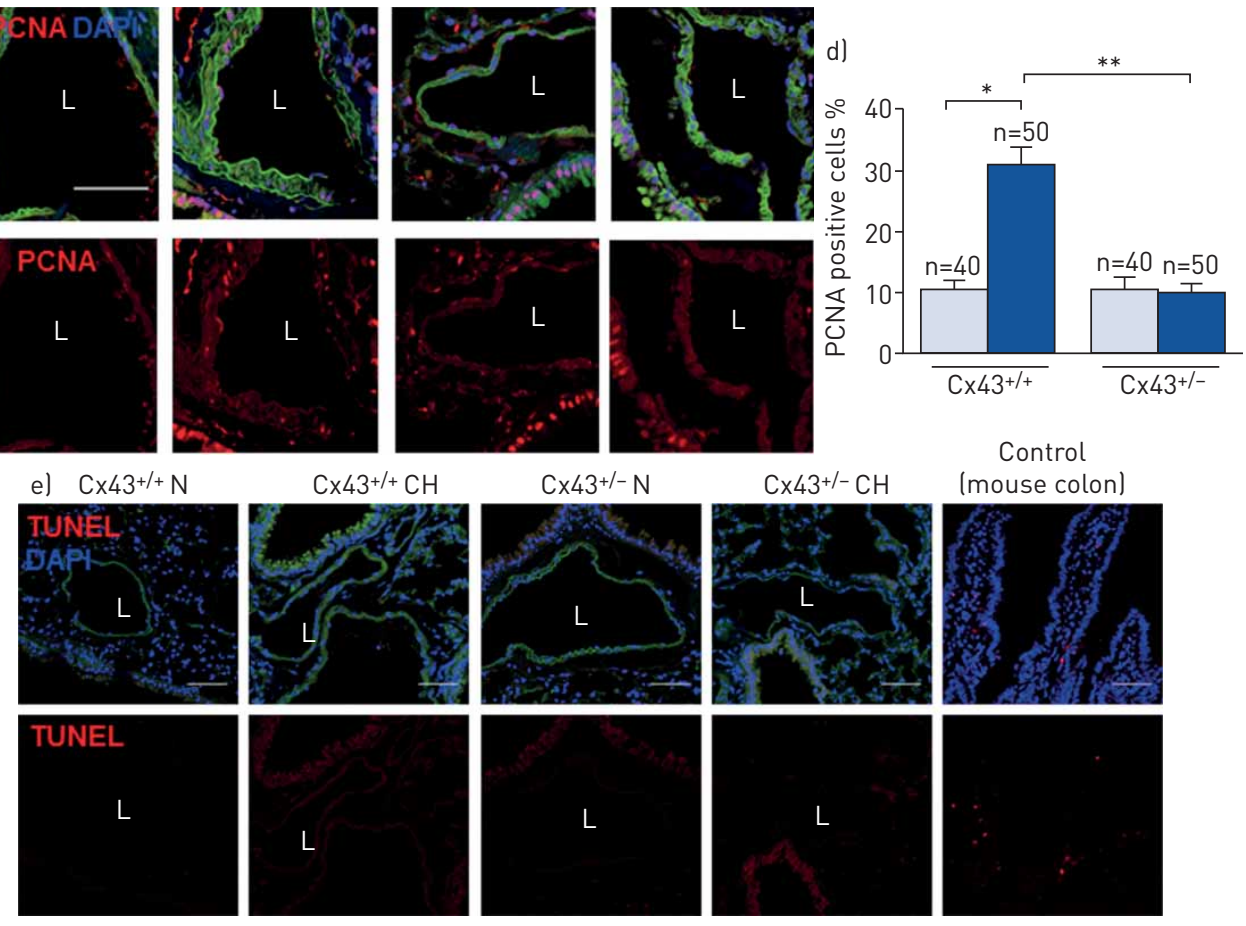

$\mathrm{C} \times 43^{+/-} \mathrm{CH}$

Control
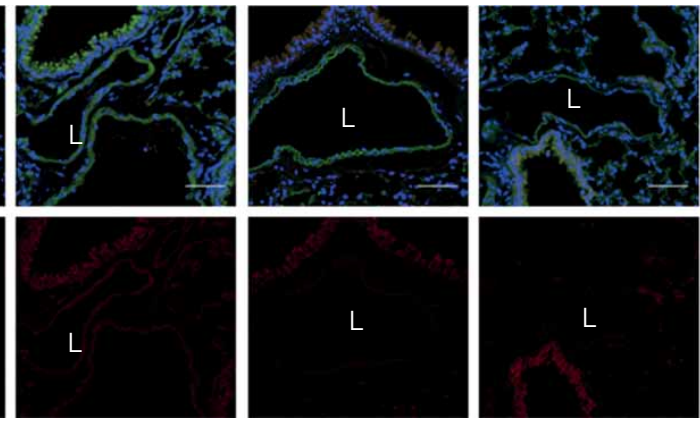

[mouse colon]
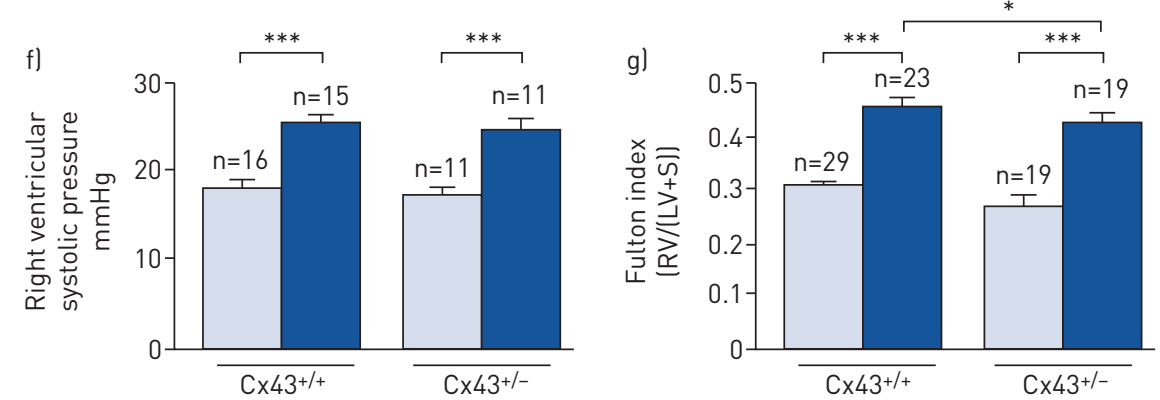

FIGURE 4 Remodelling of intrapulmonary arteries and the right ventricle in hypoxia-induced pulmonary hypertension $(\mathrm{CH}-\mathrm{PH})$ in mice, comparing $\mathrm{C} \times 43^{+/-}$mice and $\mathrm{C} \times 43^{+/+}$mice under conditions of normoxia $(\mathrm{N})$ and chronic hypoxia $(\mathrm{CH})$. Panels are as follows: (a) representative sections of intrapulmonary arteries (with haematoxylin and eosin staining); (b) percentage of the intrapulmonary arterial wall thickness in the different experimental groups as shown in (a); (c) proliferating cell nuclear antigen (PCNA) expression as assessed by immunofluorescent staining; (d) percentage of PCNA positive cells in the different experimental groups as shown in (c); (e) detection of apoptotic cells in intrapulmonary arteries from lung sections using TUNEL methodology (mouse colon was used as a positive control). Nuclei of proliferating or apoptotic cells were labelled in red $((c)$ and (e), respectively), nuclei of all cells were labelled in blue with 4',6-diamidino-2-phenylindole (DAPI) and autofluorescence of the elastic lamina was labelled in green; $(\mathrm{f})$ right-ventricular systolic pressure recordings; (g) right-ventricular remodelling lassessed by the Fulton index). Data presented are mean \pm SEM. Scale bars $=15 \mu \mathrm{m}$ for (a) and $50 \mu \mathrm{m}$ for (c) and (e); n: number of vessels from four to five mice per group for $(b)$ and $(d)$, and number of mice for $(f)$ and $(g)$; $L$ : pulmonary artery (PA) lumen. *: $p<0.05 ;{ }^{* *}: p<0.01 ;{ }^{* * *}: p<0.001$. 
a)

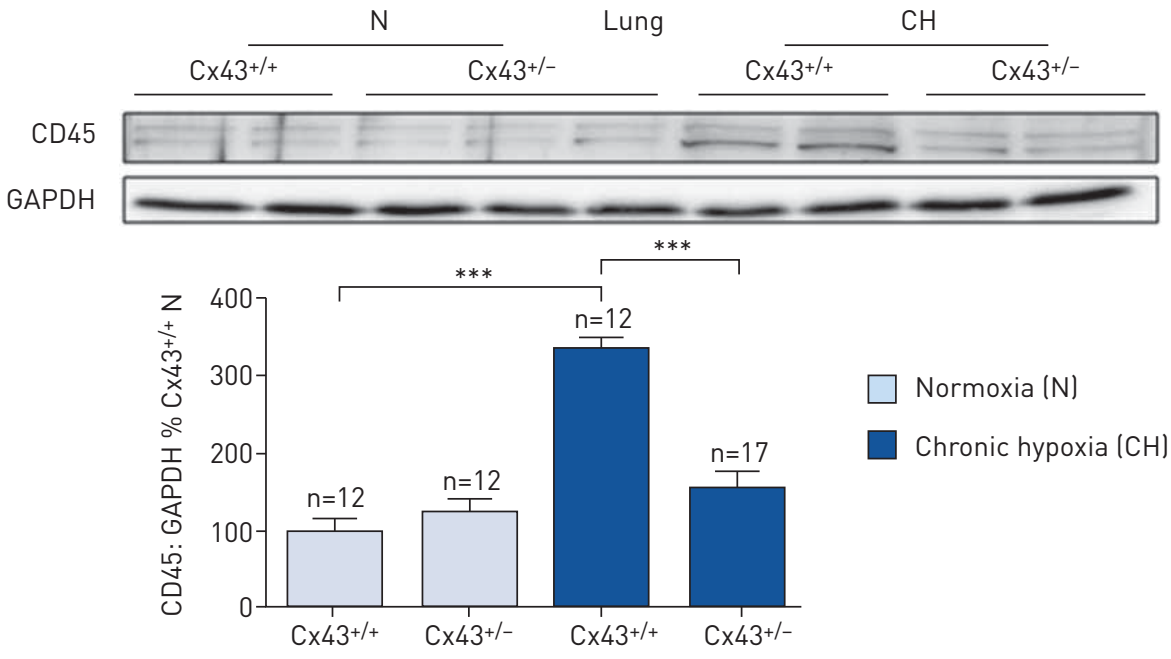

b)

$\mathrm{N}$

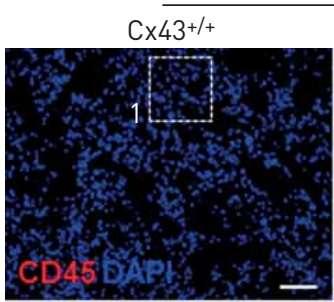

$\mathrm{C} \times 43^{+1-}$
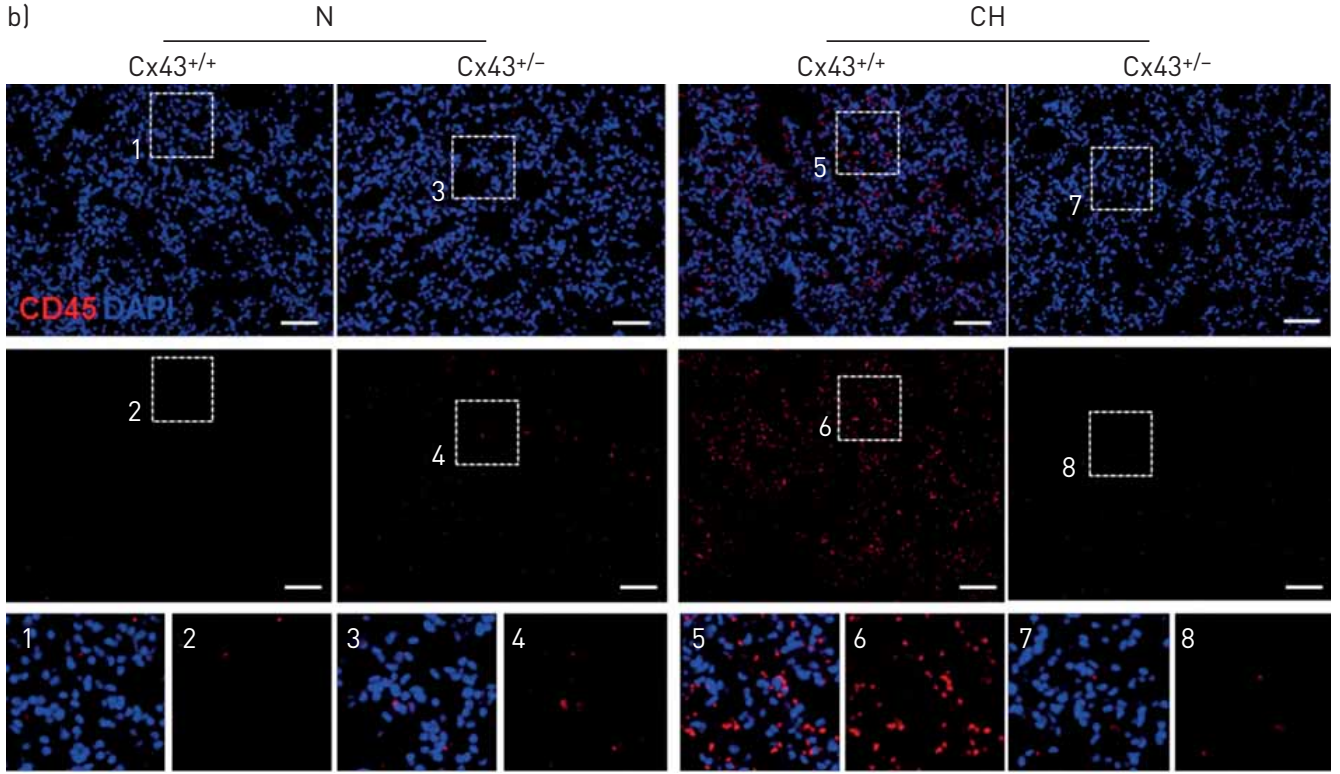

FIGURE 5 Lung inflammation in $\mathrm{C} \times 43^{+/-}$mice compared with $\mathrm{C} \times 43^{+/+}$mice under conditions of normoxia (N) and chronic hypoxia (CH). Expression of CD45 (a leukocyte marker) was assessed by (a) Western Blot analysis in whole lung homogenates and by (b) immunofluorescent labelling in lung sections (red labelling). For Western Blot experiments, CD45 expression was normalised to glyceraldehyde-3-phosphate dehydrogenase (GAPDH) and expressed as a percentage of $\mathrm{CD} 45$ expression in lungs from $\mathrm{Cx} 43^{+/+}$mice under $\mathrm{N}$ conditions. For immunofluorescent labelling, nuclei were labelled in blue with 4',6-diamidino-2-phenylindole (DAPI). Images 1-8 at the bottom of panel (b) are expansions of the similarly marked squares in the respective main images. Data presented are mean \pm SEM. Scale bars $=100 \mu \mathrm{m}$. $\mathrm{n}$ : number of mice. ${ }^{* * *}: \mathrm{p}<0.001$.

not show any obvious endothelial damage in PAs from all groups of mice, indicating that endothelium damage cannot be used to explain this dysfunction.

\section{Cx43 expression in right and left ventricles in mice}

Cx43 expression in right-heart versus left-heart ventricles was compared for all experimental groups of mice. Both $\mathrm{Cx} 43$ mRNA (figures $7 \mathrm{a}$ and $7 \mathrm{~b}$ ) and protein (figures $7 \mathrm{c}$ and $7 \mathrm{~d}$ ) were similarly expressed in right-heart and left-heart ventricles from $\mathrm{Cx} 43^{+/+}$mice under $\mathrm{N}$ and $\mathrm{CH}$ conditions. As expected, $\mathrm{Cx} 43$ mRNA and protein were significantly decreased in $\mathrm{Cx} 43^{+/-}$mice compared to $\mathrm{Cx} 43^{+/+}$mice under both $\mathrm{N}$ and $\mathrm{CH}$ conditions. However, as in $\mathrm{Cx} 43^{+/+}$mice, both $\mathrm{Cx} 43$ mRNA and protein were similarly expressed in right-heart and left-heart ventricles from $\mathrm{Cx} 43^{+/-}$mice under $\mathrm{N}$ and $\mathrm{CH}$ conditions. Moreover, mRNA levels for $\mathrm{Cx} 37$ and $\mathrm{Cx} 40$ were not significantly different between the four experimental groups of mice for both right-heart and left-heart ventricles (supplemental figures S11a and S11b), confirming that as in PAs there was no compensation in the heart for the partial $\mathrm{Cx} 43$ deletion by $\mathrm{Cx} 37$ or $\mathrm{Cx} 40$ altered expression. 
$\mathrm{N}$
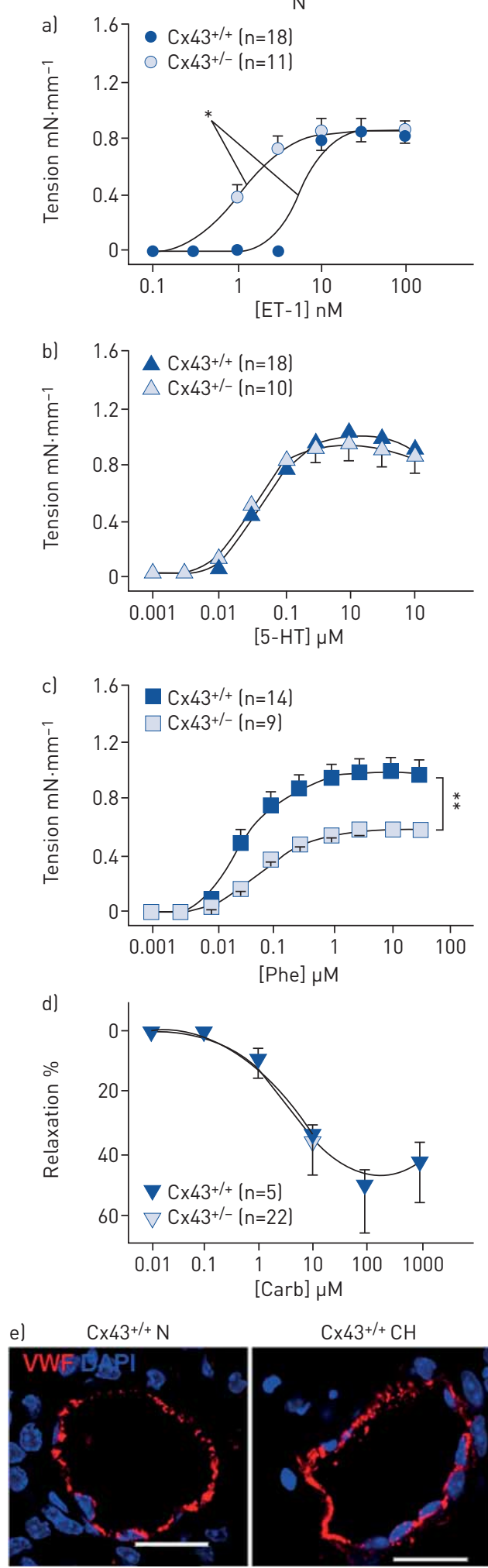

$\mathrm{CH}$

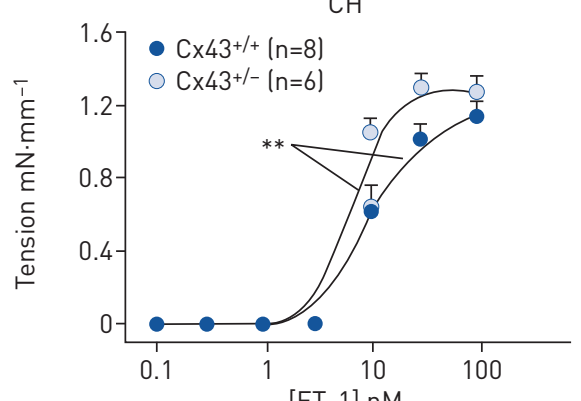

[ET-1] nM
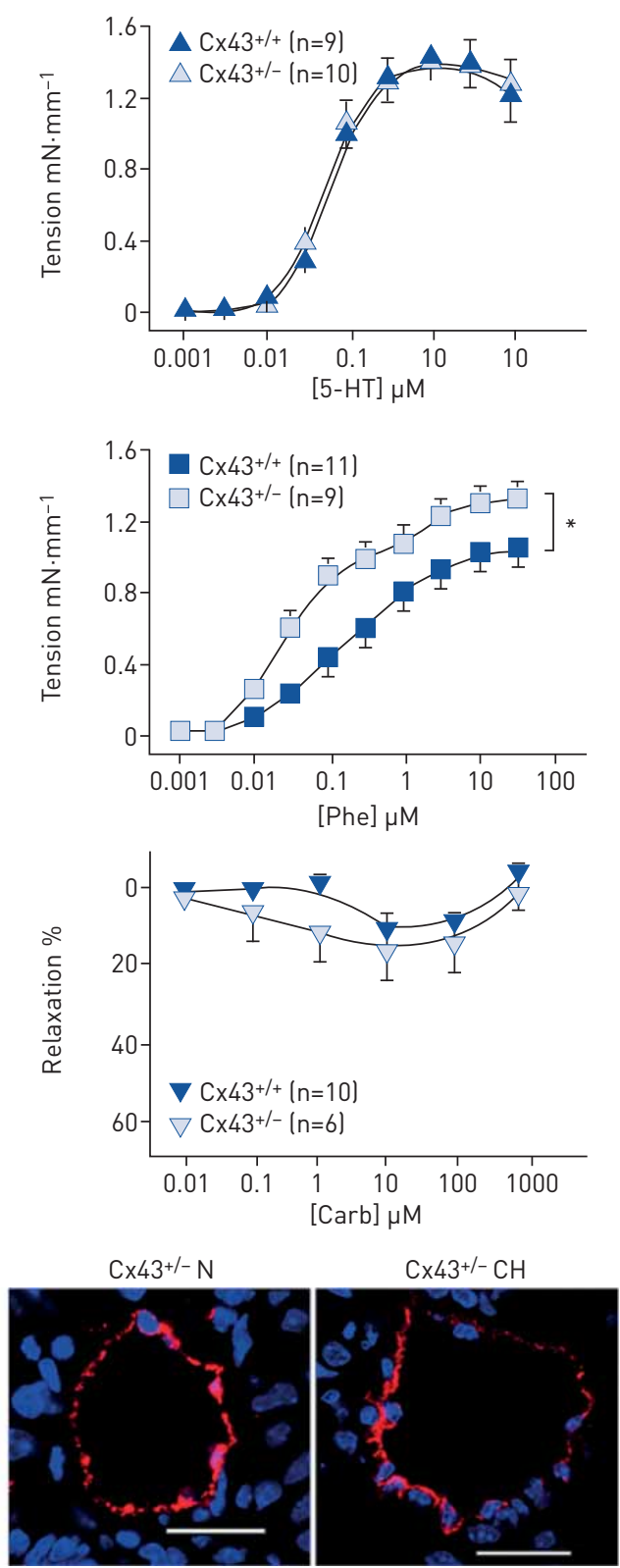

FIGURE 6 Pulmonary arterial reactivity in $\mathrm{C} \times 43^{+/-}$mice compared with $\mathrm{C} \times 43^{+/+}$mice under conditions of normoxia $(\mathrm{N})$ and chronic hypoxia $(\mathrm{CH})$. Contraction of intrapulmonary arterial rings was induced by cumulative concentrations of either (a) endothelin-1 (ET-1; 0.1-100 nM), (b) serotonin (5-HT; 0.001-10 $\mu \mathrm{M}$ ) or (c) phenylephrine (Phe; 0.001 to $30 \mu \mathrm{M}$ ). Relaxation of intrapulmonary arterial rings was induced by cumulative concentrations of carbachol (Carb; 0.01 to $1000 \mu \mathrm{M}$ ) (d) on vessels pre-contracted with Phe (1 $\mu \mathrm{M})$. Panel (e) shows endothelium labelling in red with von Willebrand Factor (vWF). Nuclei are labelled in blue with 4',6-diamidino-2-phenylindole (DAPI). Data presented are mean \pm SEM. Scale bars $=20 \mu \mathrm{m}$. n: number of vessels from at least three mice per condition. ${ }^{*}: p<0.05 ;{ }^{* *}: p<0.01$. 
Normoxia (N)

a)

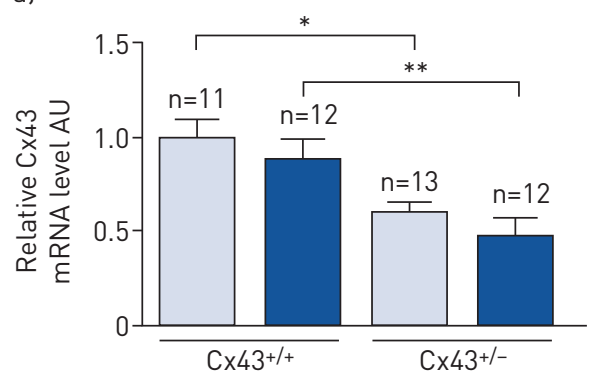

c)

$\mathrm{C} \times 43$

GAPDH

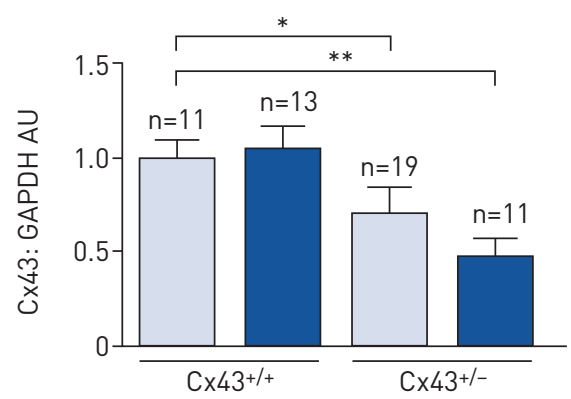

e)

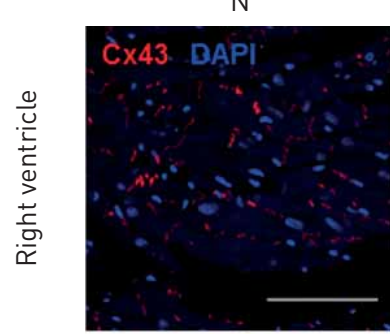

$\mathrm{C} \times 43^{+/+}$
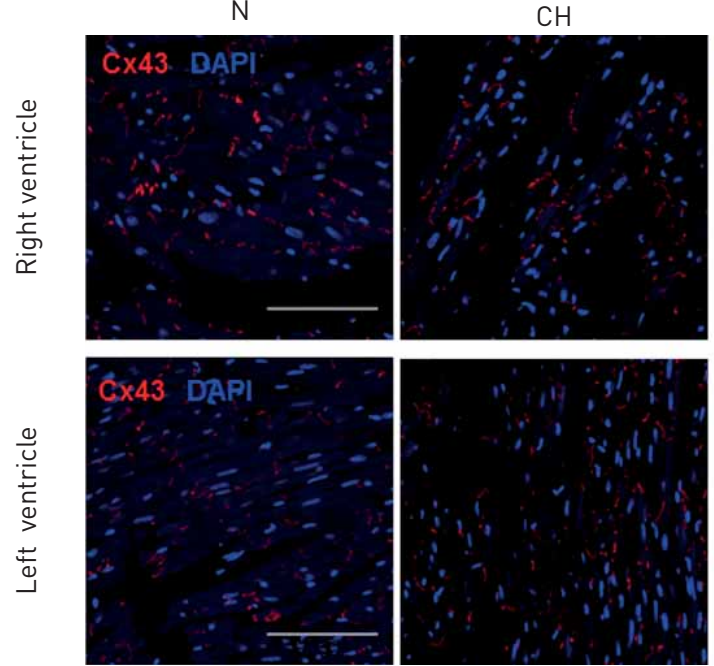

Chronic hypoxia $(\mathrm{CH})$

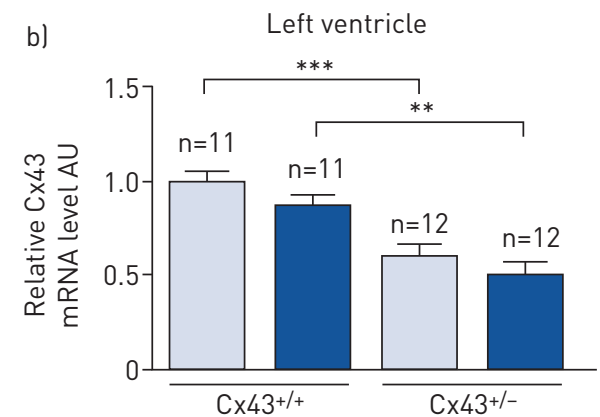

d)

Left ventricle
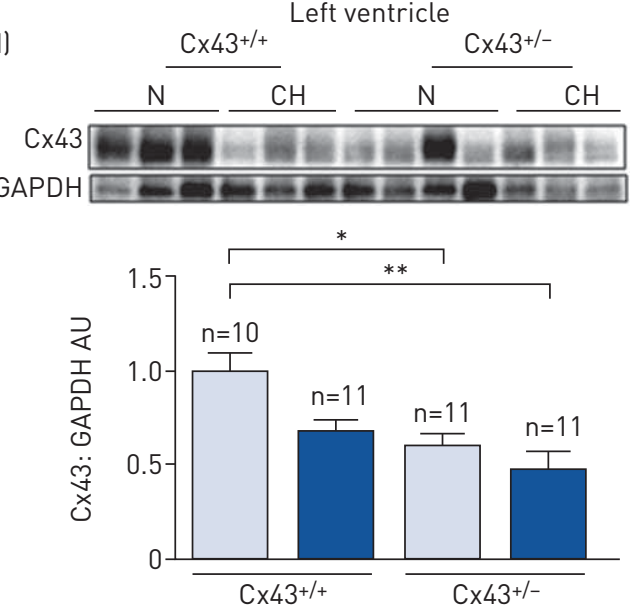

$\mathrm{C} \times 43^{+/-}$
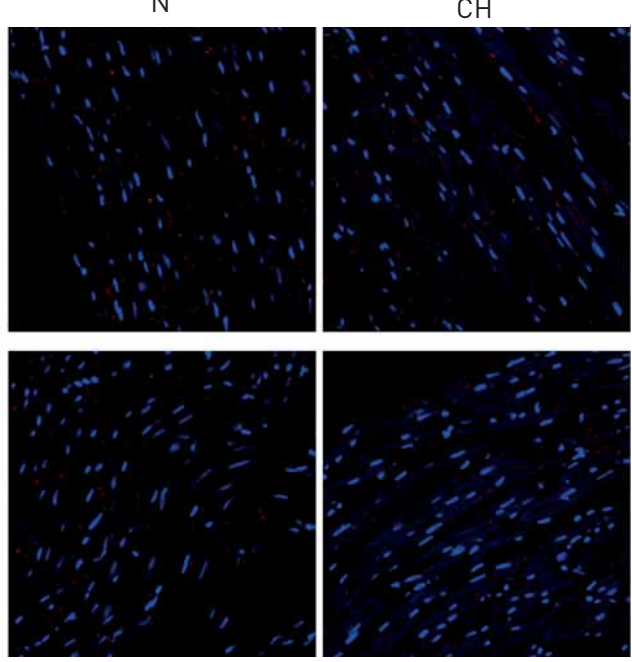

FIGURE 7 Expression and localisation of $\mathrm{C} \times 43$ in right-heart versus left-heart ventricles from $\mathrm{C} \times 43^{+/-}$mice compared with $\mathrm{C} \times 43^{+/+}$mice under conditions of normoxia (N) and chronic hypoxia (CH). Cx43 mRNA levels ((a) and (b)) and protein levels ((c) and (d)) were assessed by quantitative PCR and Western Blot analysis. Cx43 protein expression was normalised to glyceraldehyde-3-phosphate dehydrogenase (GAPDH). Localisation of Cx43 protein as assessed by immunofluorescent staining in sections of right-heart or left-heart ventricles is shown in panel (e). Cx43 is labelled in red and nuclei are labelled in blue using 4',6-diamidino-2-phenylindole (DAPI). Data presented are mean \pm SEM. Scale bars $=100 \mu \mathrm{m}$. n: number of mice. ${ }^{*}: p<0.05 ;{ }^{* *}: p<0.01{ }^{* * *}$ : $\mathrm{p}<0.001$.

\section{Discussion}

In the present study, the first complete description of the deleterious effects of $\mathrm{Cx} 43$ in $\mathrm{CH}-\mathrm{PH}$ in mice is provided. Decrease in $\mathrm{Cx} 43$ expression is shown to attenuate $\mathrm{CH}$-induced PA remodelling and lung inflammation. Partial decrease of $\mathrm{Cx} 43$ protein expression also modifies PA vasoreactivity, another 
important characteristic of $\mathrm{PH}$. Likewise, in human $\mathrm{CH}-\mathrm{PH}, \mathrm{Cx} 43$ protein expression varies and this variation is specific to the $\mathrm{PH}$ form (i.e. $\mathrm{CH}-\mathrm{PH}$ versus $\mathrm{IPAH}$ ), supporting a specific role of $\mathrm{Cx} 43$ according to the $\mathrm{PH}$ form. It is thus suggested that $\mathrm{Cx} 43$ may be a promising therapeutic option to consider, particularly for $\mathrm{CH}-\mathrm{PH}$ that lacks specific treatments [1]. Further work will need to be performed in animal models in vivo in order to confirm the beneficial role of blocking $\mathrm{Cx} 43$.

In patients with $\mathrm{CH}-\mathrm{PH}$, an important increase in $\mathrm{Cx} 43$ protein levels was clearly demonstrated for the first time. In patients with IPAH, Cx43 expression was decreased in PA-SMCs whereas it was not changed in PM-ECs, supporting the idea that the vascular $\mathrm{Cx} 43$ protein level is a distinctive characteristic of these two severe forms of $\mathrm{PH}$. Although such experiments have never been performed previously on these human cells, it has been consistently shown that $\mathrm{Cx} 43$ protein is decreased in blood-derived endothelial-like cells in patients with IPAH [27]. Likewise, the expression of Cx37 and Cx40 (two other Cx commonly expressed in resistant vessels [28]) is also decreased in lung tissues and in PA-ECs from patients with IPAH [12]. For Cx37 expression, a tendency to decrease was consistently observed in PA-SMCs from patients with IPAH. In addition, the present study showed that $1 \%$ oxygen over $48 \mathrm{~h}$ induced a five-fold increase in the amount of $\mathrm{Cx} 43 \mathrm{mRNA}$ in cultured PA-SMCs from control patients, indicating that hypoxia may be responsible for $\mathrm{Cx} 43$ protein increase in PAs from patients with $\mathrm{CH}-\mathrm{PH}$. Such Cx43 sensitivity to hypoxia has already been shown in the systemic circulation, specifically in cultured smooth muscle cells from rat thoracic aorta exposed to 2\% oxygen over $6 \mathrm{~h} \mathrm{[29].} \mathrm{Therefore,} \mathrm{our}$ study indicates that hypoxia may explain the difference in Cx43 PA expression between patients with $\mathrm{CH}-\mathrm{PH}$ versus IPAH. In the present study we have not addressed the mechanisms involved in hypoxia-induced $\mathrm{Cx} 43$ regulation; however, a previous study has shown that HIF-1 $\alpha$ is able to increase Cx43 expression, through the activation of HRE-5 present in the Cx43 promoter region in human melanoma cell lines [30]. We can thus speculate that such a mechanism could be responsible for the hypoxia-induced Cx43 increase in human PAs (figures 1a and 2, and supplemental figures S1 and S2).

Some of our results regarding $\mathrm{Cx}$ expression conflict with previous studies. For instance, we observed similar $\mathrm{Cx} 43$ expression under $\mathrm{N}$ and $\mathrm{CH}$ conditions and similar $\mathrm{Cx} 37$ and $\mathrm{Cx} 40 \mathrm{mRNA}$ levels in $\mathrm{Cx} 43^{+/+}$ versus $\mathrm{Cx} 43^{+/-}$mice independent of the conditions tested in both PAs and hearts (supplementary figures S6 and S11), indicating that $\mathrm{Cx} 43$ knock-down was not compensated by variations in expression of $\mathrm{Cx}$ with a homology close to $\mathrm{Cx} 43$ and expressed in PAs of mice. However, HтEт et al. [11] demonstrated 1) a decrease in Cx43 mRNA expression in PAs from both $\mathrm{Cx} 43^{+/+}$and $\mathrm{Cx} 43^{+/-}$mice with $\mathrm{CH}-\mathrm{PH}$ compared to $\mathrm{N}$ mice; and 2) a decrease in $\mathrm{Cx} 37$ and $\mathrm{Cx} 40$ mRNA expression in $\mathrm{N} \mathrm{Cx} 43^{+/-}$mice compared to $\mathrm{N}$ $\mathrm{C} \times 43^{+/+}$mice. It should be noted however that they used a C57BL6 mouse strain whereas we used a CD1 mouse strain. Furthermore, they induced $\mathrm{CH}$ over 14 days whereas we induced $\mathrm{CH}$ over 21 days.

Moreover, it should be noted that although $\mathrm{Cx} 43$ expression is increased in human PAs (figures 1a and 2 and supplementary figures S1 and S2) this is not the case in PAs from mice (figure 3). However, $\mathrm{Cx} 43$ protein expression has been quantified by performing Western Blot experiments on whole intrapulmonary arteries from mice and therefore we detected $\mathrm{Cx} 43$ from cytosol as well as from all cellular membranes. Interestingly, $\mathrm{Cx} 43$ expression seems to be more abundant close to the plasma membrane in $\mathrm{CH}-\mathrm{PH}$ $\mathrm{Cx} 43^{+/+}$mice compared to $\mathrm{N} \mathrm{Cx} 43^{+/+}$mice (supplementary figure S4). Such results could explain the discrepancy between Western Blot experiments on human PAs and mice PAs. Moreover, functional Cx43 is phosphorylated and we can thus speculate that although the total amount of Cx43 is similar under normoxic and hypoxic conditions, the phosphorylation state of $\mathrm{Cx} 43$ could be higher in mice under hypoxic conditions.

In $\mathrm{Cx} 43^{+/+}$mice, PA remodelling characterised by smooth muscle and endothelial cell proliferation, and inflammation revealed by immune cell infiltration, were observed under $\mathrm{CH}$ conditions (figures 4 and 5). In contrast, such processes did not appear in $\mathrm{Cx} 43^{+/-}$mice with $\mathrm{CH}-\mathrm{PH}$, suggesting that blocking $\mathrm{Cx} 43$ would have a beneficial effect in $\mathrm{CH}-\mathrm{PH}$. Since $\mathrm{Cx} 43$ is known to be decreased in the hypertrophic right ventricle in a classical monocrotaline PH model in rats $[19,20,31]$ and $\mathrm{Cx} 43^{-/-}$mice are born with a lethal defect (due to an abnormal right-ventricular outflow tract from the heart [25]), one would expect a harmful effect on the heart when blocking $\mathrm{Cx} 43$. In fact, both right-ventricular systolic pressure and hypertrophy were similarly increased in $\mathrm{Cx}_{4} 3^{+/+}$and $\mathrm{Cx} 43^{+/-}$mice with $\mathrm{CH}-\mathrm{PH}$ (figures $4 \mathrm{f}$ and $4 \mathrm{~g}$ ). However, it should be noted that the increase in right-ventricular hypertrophy (as assessed by the Fulton index) was statistically significantly smaller in $\mathrm{Cx} 43^{+/-}$mice compared to $\mathrm{Cx} 43^{+/+}$mice with $\mathrm{CH}-\mathrm{PH}$. Consequently, $\mathrm{Cx} 43^{+/-}$mice with $\mathrm{CH}-\mathrm{PH}$ were still alive and, although high, right-ventricular systolic pressure and Fulton index were not higher than in $\mathrm{Cx} 43^{+/+}$mice with $\mathrm{CH}-\mathrm{PH}$. Interestingly, in all groups of mice, HR and heart capillary density were similar and cardiomyocytes apoptosis was absent (supplementary figures S7c and S8). Therefore, blocking Cx43 functions or reducing $\mathrm{Cx} 43$ expression level should not worsen $\mathrm{PH}$ cardiac symptoms. Intratracheal instillation of ${ }^{43} \mathrm{Gap} 26$, a peptide that specifically inhibits Cx43, had a consistently beneficial effect on lipopolysaccharide (LPS)-induced lung inflammation in mice without any obvious 
deleterious side effects [32]. Importantly, Cx43 decrease in the heart following PH has only been previously shown in a monocrotaline $\mathrm{PH}$ model, considered to be closer to IPAH, but not in $\mathrm{CH}-\mathrm{PH}$ models. Altogether, the present results should strengthen the interest in targeting $\mathrm{Cx} 43$ in $\mathrm{CH}-\mathrm{PH}$.

The role of $\mathrm{Cx} 43$ in PA vasoreactivity, another important feature that participates in PH development [33], was also addressed. PA vasoreactivity was tested in response to ET-1 and 5-HT, whose circulating concentrations are known to increase in $\mathrm{PH}$ [34-39]. PA vasoreactivity to ET-1 was increased in $\mathrm{Cx} 43^{+/-}$ mice compared to $\mathrm{Cx} 43^{+/+}$mice, under both $\mathrm{N}$ and $\mathrm{CH}$ conditions (figure 6a), whereas PA vasoreactivity to 5-HT was identical in all groups of mice (figure $6 \mathrm{~b}$ ). Such results are consistent with those observed by Hтет et al. [11] in $\mathrm{Cx} 43^{+/-}$C57BL6 mice. Such a role for $\mathrm{Cx} 43$ on PA vasoreactivity to ET-1 may explain why, despite PA remodelling and inflammation being absent, right-ventricular systolic pressure and Fulton index remained high in $\mathrm{Cx} 43^{+/-}$mice with $\mathrm{CH}-\mathrm{PH}$ compared to $\mathrm{Cx} 43^{+/+}$mice with $\mathrm{CH}-\mathrm{PH}$. Such ET-1 induced PA hyper-reactivity in $\mathrm{Cx} 43^{+/-}$mice can be considered as a minor secondary effect since it could be treated with endothelin receptor antagonists that have already been shown to be of benefit for patients [1]. Collectively, these results indicate that $\mathrm{Cx} 43$ plays an important role in PA vasoreactivity, under both physiological and pathophysiological conditions ( $\mathrm{N}$ and $\mathrm{CH}-\mathrm{PH}$, respectively), as already shown in rat and C57BL6 mouse pulmonary circulation $[7,8,11]$.

In conclusion, the present study demonstrates for the first time that partial decrease of Cx43 expression suppresses PA remodelling and inflammation in mice with $\mathrm{CH}-\mathrm{PH}$. It also shows that even in the absence of pulmonary vascular remodelling, right-ventricular pressures and hypertrophy remain high in $\mathrm{Cx} 43^{+/-}$ mice with $\mathrm{CH}-\mathrm{PH}$. Importantly, a slight reduction in cardiac hypertrophy is observed, suggesting that blocking of Cx43 might have some beneficial effect on the heart. Since decrease in Cx43 expression also enhances PA vasoreactivity, we suggest that both $\mathrm{Cx} 43$ and ET-1 pathway inhibitors could be a new therapeutic option that might be further explored for $\mathrm{PH}$. Finally, since $\mathrm{Cx} 43$ was increased in PAs from patients with $\mathrm{CH}-\mathrm{PH}$ but not in patients with $\mathrm{IPAH}$, we suggest that a treatment combining $\mathrm{Cx} 43$ and ET-1 blockers could be considered especially for patients with $\mathrm{CH}-\mathrm{PH}$.

Acknowledgements: The microscopy for TUNEL assay and labelling of Cx43, PCNA and vWF in mice lungs or heart sections was done in the Bordeaux Imaging Center, a service unit of the CNRS-INSERM and Bordeaux University, and member of the national infrastructure France BioImaging. We thank Thierry Leste-Lasserre for his design of the primers at the Plateforme Transcriptome (Magendie Neurocenter, Bordeaux, France, a service unit of the CNRS-INSERM and Bordeaux University).

Support statement: This study was supported by the Fondation du Souffle and the Fonds de Dotation Recherche en Santé Respiratoire. B. Rode is funded by La Fondation Lefoulon Delalande. Funding information for this article has been deposited with the Crossref Funder Registry.

Conflict of interest: C. Bouvard has nothing to disclose. N. Genet has nothing to disclose. C. Phan has nothing to disclose. B. Rode has nothing to disclose. R. Thuillet has nothing to disclose. L. Tu has nothing to disclose. P. Robillard has nothing to disclose. M. Campagnac has nothing to disclose. R. Soleti has nothing to disclose. E. Dumas De La Roque has nothing to disclose. F. Delcambre has nothing to disclose. L. Cronier has nothing to disclose. T. Parpaite has nothing to disclose. E. Maurat has nothing to disclose. P. Berger reports grants from Nycomed, Takeda, Fondation du Souffle and Fonds de Dotation Recherche en Santé Respiratoire, during the conduct of the study; grants and personal fees for lectures, advisory board work and travel to meetings from Novartis, personal fees for lectures and non-financial (travel) support from Chiesi, grants and personal fees for advisory board work and lectures, as well as non-financial (travel) support from Boehringer Ingelheim, personal fees for advisory board work and lectures, as well as non-financial (travel) support from AstraZeneca and Sanofi, personal fees for advisory board work and lectures from Menarini, and personal fees for lectures from TEVA, outside the submitted work. J-P. Savineau has nothing to disclose. R. Marthan has nothing to disclose. C. Guignabert has nothing to disclose. V. Freund-Michel has nothing to disclose. C. Guibert has nothing to disclose.

\section{References}

1 Galie N, Humbert M, Vachiery JL, et al. 2015 ESC/ERS Guidelines for the diagnosis and treatment of pulmonary hypertension. Eur Heart J 2016; 37: 67-119.

2 Guibert C, Marthan R, Savineau JP. Modulation of ion channels in pulmonary arterial hypertension. Curr Pharm Des 2007; 13: 2443-2455.

3 Humbert M, Lau EM, Montani D, et al. Advances in therapeutic interventions for patients with pulmonary arterial hypertension. Circulation 2014; 130: 2189-2208.

4 Rabinovitch M, Guignabert C, Humbert M, et al. Inflammation and immunity in the pathogenesis of pulmonary arterial hypertension. Circ Res 2014; 115: 165-175.

5 Tamura Y, Phan C, Tu L, et al. Ectopic upregulation of membrane-bound IL6R drives vascular remodeling in pulmonary arterial hypertension. J Clin Invest 2018; 128: 1956-1970.

6 Morrell NW, Adnot S, Archer SL, et al. Cellular and molecular basis of pulmonary arterial hypertension. $J \mathrm{Am}$ Coll Cardiol 2009; 54: S20-S31.

7 Billaud M, Marthan R, Savineau JP, et al. Vascular smooth muscle modulates endothelial control of vasoreactivity via reactive oxygen species production through myoendothelial communications. PLoS One 2009; 4: e6432.

8 Billaud M, Dahan D, Marthan R, et al. Role of the gap junctions in the contractile response to agonists in pulmonary artery from two rat models of pulmonary hypertension. Respir Res 2011; 12: 30. 
9 Chen M, Liu Y, Yi D, et al. Tanshinone IIA promotes pulmonary artery smooth muscle cell apoptosis in vitro by inhibiting the JAK2/STAT3 signaling pathway. Cell Physiol Biochem 2014; 33: 1130-1138.

10 Freund-Michel V, Muller B, Marthan R, et al. Expression and role of connexin-based gap junctions in pulmonary inflammatory diseases. Pharmacol Ther 2016; 164: 105-119.

11 Htet M, Nally JE, Shaw A, et al. Connexin 43 plays a role in pulmonary vascular reactivity in mice. Int J Mol Sci 2018; 19: E1891.

12 Kim J, Hwangbo C, Hu X, et al. Restoration of impaired endothelial myocyte enhancer factor 2 function rescues pulmonary arterial hypertension. Circulation 2015; 131: 190-199.

13 Yang L, Yin N, Hu L, et al. Sildenefil increases connexin 40 in smooth muscle cells through activation of BMP pathways in pulmonary arterial hypertension. Int J Clin Exp Pathol 2014; 7: 4674-4684.

14 Yen $\mathrm{CH}$, Tsai TH, Leu S, et al. Sildenafil improves long-term effect of endothelial progenitor cell-based treatment for monocrotaline-induced rat pulmonary arterial hypertension. Cytotherapy 2013; 15: 209-223.

15 Brisset AC, Isakson BE, Kwak BR. Connexins in vascular physiology and pathology. Antioxid Redox Signal 2009; 11: $267-282$.

16 Johnstone SR, Kroncke BM, Straub AC, et al. MAPK phosphorylation of connexin 43 promotes binding of cyclin E and smooth muscle cell proliferation. Circ Res 2012; 111: 201-211.

17 Liao Y, Regan CP, Manabe I, et al. Smooth muscle-targeted knockout of connexin43 enhances neointimal formation in response to vascular injury. Arterioscler Thromb Vasc Biol 2007; 27: 1037-1042.

18 Hardziyenka M, Campian ME, Verkerk AO, et al. Electrophysiologic remodeling of the left ventricle in pressure overload-induced right ventricular failure. J Am Coll Cardiol 2012; 59: 2193-2202.

19 Sasano C, Honjo H, Takagishi Y, et al. Internalization and dephosphorylation of connexin43 in hypertrophied right ventricles of rats with pulmonary hypertension. Circ J 2007; 71: 382-389.

20 Tanaka Y, Takase B, Yao T, et al. Right ventricular electrical remodeling and arrhythmogenic substrate in rat pulmonary hypertension. Am J Respir Cell Mol Biol 2013; 49: 426-436.

21 Freund-Michel V, Cardoso Dos Santos M, Guignabert C, et al. Role of nerve growth factor in development and persistence of experimental pulmonary hypertension. Am J Respir Crit Care Med 2015; 192: 342-355.

22 Rodat-Despoix L, Aires V, Ducret T, et al. Signalling pathways involved in the contractile response to 5-HT in the human pulmonary artery. Eur Respir J 2009; 34: 1338-1347.

$23 \mathrm{Tu}$ L, De Man FS, Girerd B, et al. A critical role for p130Cas in the progression of pulmonary hypertension in humans and rodents. Am J Respir Crit Care Med 2012; 186: 666-676.

24 Parpaite T, Cardouat G, Mauroux M, et al. Effect of hypoxia on TRPV1 and TRPV4 channels in rat pulmonary arterial smooth muscle cells. Pflugers Arch 2016; 468: 111-130.

25 Reaume AG, de Sousa PA, Kulkarni S, et al. Cardiac malformation in neonatal mice lacking connexin43. Science 1995; 267: 1831-1834

26 Hara Y, Sassi Y, Guibert C, et al. Inhibition of MRP4 prevents and reverses pulmonary hypertension in mice. J Clin Invest 2011; 121: 2888-2897.

27 Tsang H, Leiper J, Hou Lao K, et al. Role of asymmetric methylarginine and connexin 43 in the regulation of pulmonary endothelial function. Pulm Circ 2013; 3: 675-691.

28 Johnstone S, Isakson B, Locke D. Biological and biophysical properties of vascular connexin channels. Int Rev Cell Mol Biol 2009; 278: 69-118.

29 Cowan DB, Jones M, Garcia LM, et al. Hypoxia and stretch regulate intercellular communication in vascular smooth muscle cells through reactive oxygen species formation. Arterioscler Thromb Vasc Biol 2003; 23: 1754-1760.

30 Tittarelli A, Janji B, Van Moer K, et al. The selective degradation of synaptic connexin 43 protein by hypoxia-induced autophagy impairs natural killer cell-mediated tumor cell killing. J Biol Chem 2015; 290: 23670-23679.

31 Ahmed LA, Rizk SM, El-Maraghy SA. Pinocembrin ex vivo preconditioning improves the therapeutic efficacy of endothelial progenitor cells in monocrotaline-induced pulmonary hypertension in rats. Biochem Pharmacol 2017; 138: 193-204.

32 Sarieddine MZ, Scheckenbach KE, Foglia B, et al. Connexin43 modulates neutrophil recruitment to the lung. J Cell Mol Med 2009; 13: 4560-4570.

33 Figueroa XF, Duling BR. Gap junctions in the control of vascular function. Antioxid Redox Signal 2009; 11: 251-266.

34 Carratu P, Scoditti C, Maniscalco M, et al. Exhaled and arterial levels of endothelin-1 are increased and correlate with pulmonary systolic pressure in COPD with pulmonary hypertension. BMC Pulm Med 2008; 8: 20.

35 Eddahibi S, Guignabert C, Barlier-Mur AM, et al. Cross talk between endothelial and smooth muscle cells in pulmonary hypertension: critical role for serotonin-induced smooth muscle hyperplasia. Circulation 2006; 113: 1857-1864.

36 Giaid A, Yanagisawa M, Langleben D, et al. Expression of endothelin-1 in the lungs of patients with pulmonary hypertension. N Engl J Med 1993; 328: 1732-1739.

37 Kereveur A, Callebert J, Humbert M, et al. High plasma serotonin levels in primary pulmonary hypertension. Effect of long-term epoprostenol (prostacyclin) therapy. Arterioscler Thromb Vasc Biol 2000; 20: 2233-2239.

38 Kim FY, Barnes EA, Ying L, et al. Pulmonary artery smooth muscle cell endothelin-1 expression modulates the pulmonary vascular response to chronic hypoxia. Am J Physiol Lung Cell Mol Physiol 2015; 308: L368-L377.

39 Stewart DJ, Levy RD, Cernacek P, et al. Increased plasma endothelin-1 in pulmonary hypertension: marker or mediator of disease? Ann Intern Med 1991; 114: 464-469. 